Оригинальные статьи / Original articles

https://doi.org/10.18619/2072-9146-2021-6-86-91 УДК 632.444.2(571.6) Н.В. Мацишина ${ }^{*}$ П.В. Фисенко,
О.А. Собко, И.В. Ким, Д.И. Волков, Н.Г. Богинская

Федеральное государственное бюджетное научное учреждение «ФНЦ агробиотехнологии Дальнего Востока им. А.К. Чайки» 692539 , Россия, Приморский край, г. Уссурийск, пос. Тимирязевский, ул. Воложенина, Зоб

*Автор для переписки:

mnathalie134@gmail.com

Благодарности. Авторы выражают признательность Р. Романчуку (Окница, Молдова, USARB) за помощь в переводе, а также доктоpy Hsin Chi (National Chung Hsing University) 32 консультации по статистической обработке результатов.

Конфликт интересов. Авторы заявляют об отсутствии конфликта интересов.

Вклад авторов. Все авторы участвовали в планировании и постановке эксперимента, а также в анализе экспериментальный данных и написании статьи.

Для цитирования: Мацишина Н.В., Фисенко П.В., Собко О.А., Ким И.В., Волков Д.И., Богинская Н.Г. Изучение изолятов Phytophthora infestans Mont. de Bary в посадках картофеля. Овощи России 2021:(6):86-91. https://doi.org/10.18619/2072-9146-2021-6-8691

Поступила в редакцию: 17.08.2021

Принята к печати: 17.09.2021

Опубликована: 25.11.2021
Изучение изолятов Phytophthora infestans Mont. de Bary в посадках картофеля

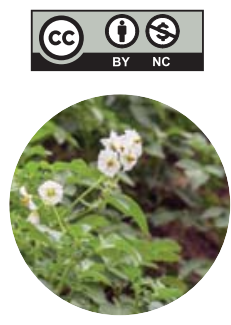

Резюме

Актуальность. Одной из самых распространенных болезней картофеля и других пасленовых является фитофторо3, вызываемый патогенным оомицетом вида Phytophthora infestans (Mont.) de Bary. В природе описано не менее 100 видов фитофторы, поражающих широкий круг видов растений. Популяция фитофторы гетерогенна и представлена расами, а также разными типами спаривания. Это приводит к быстрой адаптации патогена и появлению новых, более агрессивных и устойчивых рас. Фитофтора является паразитом, урон от которого невозможно избежать в рамках органического земледелия. Поэтому особенно важно знать особенности патогенеза и расового состава фитофторы в каждом отдельно взятом регионе выращивания пасленовых.

Методика исследований. Дифференцировкк и сбор материала из природной популяции осуществляли с использованием сортов картофеля, имеющих в геноме известные R-гены. Изоляцию и введение в культуру проводили с листьев методом влажных камер с последующим культивированием на питательных средах. Идентифицировали патоген с помощью микроскопического анализа. Культуральные фильтраты получали на жидкой среде Хелла с последующим фильтрованием и автоклавированием жидкости. Фитотоксическую активность определяли по влиянию на проростки пасленовых, злаковых и бобовых культур стандартным методом. Молекулярно-генетический анализ изолятов проводили методом ISSRанализа; праймер, амплификационная смесь и температурный профиль реакции были выбраны по литературным данным; расчет генетических характеристик проводили с использованием пакетов программ TFPGA

Результаты. Собраны и введены в культуру образцы семи изолятов Phytophthora infestans. В результате культивирования in vitro выявлены морфологические отличия, выражавшиеся в структуре и окраске мицелия, форме колоний, характере спороношения, цвета реверса и среды под колониями. Выявлены генетические отличия введенного в культуру природного материала фитофрторы, собранного с сортов картофеля, имеющие единичные гены устойчивости $\left(\mathbf{R}_{1}, \mathbf{R}_{3}, \mathbf{R}_{4}\right)$. Выявлены отличия в фитотоксической активности культуральных фильтратов исследуемых изолятов. Выделенные изоляты демонстрируют дифференциацию на фенотипическом, генетическом и физиологическом уровнях, что позволяет говорить об их принадлежности к расам.

Ключевые слова: фитофтора, расы, фитотоксическая активность, генетическое разнообразие, пасленовые, картофель, сельскохозяйственные культуры.

\section{Study of Phytophthora infestans Mont. de Bary isolates in the planting of potatoes}

\section{Abstract}

Relevance. One of the most common diseases of potatoes and other nightshade family species is late blight caused by a pathogenic oomycete of the Phytophthora infestans (Mont.) de Bary. At least 100 species of phytophthora have been described in nature, affecting a wide range of plant species. The phytophthora population is heterogeneous and is represented by races, as well as different types of mating This leads to a rapid adaptation of the pathogen and the emergence of new, more aggressive, and resistant races. Phytophthora is a parasite, the damage from which cannot be avoided within the organic farming framework. Therefore, it is particularly important to know the pathogenesis and racial composition of phytophthora in each individual region of Solanaceae cultivation.

Research methodology. Differentiation and collection of material from the natural population were carried out using potato varieties with known R-genes in the genome. Isolation and introduction into the culture were carried out from leaves with the dampening chambers method, followed by cultivation on nutrient media. The pathogen was identified by microscopic analysis. Culture filtrates were obtained on the liquid nutritious medium, followed by liquid filtration and autoclaving. Phytotoxic activity was determined by the effect on the seedlings of the nightshade, grass, and pea families by the standard method. Molecular genetic analysis of the isolates was carried out by ISSR analysis; the primer, amplification mixture, and temperature profile of the reaction were selected according to the literature data; the calculation of genetic characteristics was carried out using POPGENE software packages.

Results. Samples of seven Phytophthora infestans isolates were collected and introduced into culture. As a result of in vitro cultivation, morphological differences were revealed, expressed in the structure and color of the mycelium, the shape of the colonies, the nature of sporulation, the color of the reverse, and the medium under the colonies. The genetic differences of the natural phytophthora material introduced into the culture, collected from potato varieties with single resistance genes $\left(R_{1}, R_{3}, R_{4}\right)$, were revealed. Differences in the phytotoxic activity of the studied isolates' cultural filtrates were revealed. The isolated isolates demonstrate differentiation at the phenotypic, genetic and physiological levels, which allows us to speak about their belonging to races.

Keywords: Phytophthora, races, phytotoxic activity, genetic diversity, nightshade, potatoes, crops 


\section{Введение}

дной из самых распространенных болезней картофеля является фитофтороз, вызываемый патогенным оомицетом вида Phytophthora infestans (Mont.) de Bary. Описано не менее 100 видов фитофторы, поражающих широкий круг видов растений [1]. Фитофтороз особенно сильно поражает растения семейства паслёновые (Solanaceae). Основные пути распространения патогена - с капельной влагой, ветром в виде спор, а также с зараженным семенным материалом. Популяция фитофторы гетерогенна и представлена расами, которые выделяют на основании взаимоотношений с конкретными генотипами растений хозяев, имеющими специфические гены устойчивости, и более 100 генотипов выявлены на основании изучения изменчивости молекулярно-генетическими методами во всем мире. Кроме того, имеется два типа спаривания [2]. Все это приводит к быстрой адаптации патогена к противодействию как естественного, так и антропогенного характера и появлению новых, более агрессивных и устойчивых рас. Большинство собственных генов устойчивости картофеля к фитофторе потеряло актуальность, что привело к необходимости введения генов диких родственников для обеспечения иммунности к патогену [3]

Кроме того, стоит признать, что Phytophthora infestans является чуть ли не единственным паразитом, урон от которого невозможно избежать в рамках органического земледелия, так как лечению эта болезнь практически не поддается, можно только задержать ее развитие или предотвратить ее появление. Поэтому особенно важно знать особенности патогенеза и расового состава фитофторы в каждом отдельно взятом регионе выращивания пасленовых [4]

Цель работы - изучение расового состава Phytophthora infestans локальной популяции на посадках картофеля ФГБНУ «ФНЦ агробиотехнологий Дальнего Востока им. А.К. Чайки», исследование фенотипических, физиологических и генетических особенностей выделенных рас.

\section{Задачи:}

1. Сбор, изоляция и дифференциация рас патогена с помощью сортов с известной генотипической характеристикой в отношении фитофтороза (сорта дифференциаторы);

2. Идентификация и культивирование чистых культур изолятов in vitro;

3. Исследование морфологических, физиологических, генетических признаков выделенных изолятов для доказательства их различного происхождения и принадлежности к расам.

\section{Материал и методика}

В эксперименте использовали сорта картофеля, имеющие в геноме известные R-гены: Ранняя Роза, Приекульский ранний, Камераз $\left(\mathrm{R}_{1}\right)$, Изола $\left(\mathrm{R}_{4}\right)$, Эпока $\left(R_{3} R_{4}\right)$, Анко, Вулкан, Сузанна $\left(R_{1} R_{3}\right)$, Красноуфимский $\left(R_{2} R_{4}\right)$, Жуковский ранний $\left(R_{3}\right)$, Невский $\left(R_{1} R_{2}\right)$. Картофель высаживали в полевых условиях (с.Пуциловка, Приморский край). Для выявления возбудителя фитофтороза проводили сбор листьев с характерными краевыми некрозами [5].

\section{Изоляция, введение в культуру, определение патогена}

Листья закладывали во влажные камеры до появления мицелия, после чего производили пересев кусочком мицелия на клубень картофеля. Их помещали во влажную камеру на 4-5 дней при температуре $18 \ldots 20^{\circ} \mathrm{C}$. Через 4-5 дней с ломтиков клубней образовавшийся мицелий культивировали на среду Хелла, содержащую $\mathrm{KH}_{2} \mathrm{PO}_{4}-0,5$ г, $\mathrm{MgSO}_{4}-0,25$ г, $\mathrm{FeSO}_{4}-0,01$ г, глюкоза - 25 г, аспарагин 0,5 г, тиамин - 0,002 г, рибофлавин - 0,002 г. Порядковые номера изолятов соответствовали названию сорта картофеля и дифференцируемой им расы патогена с присвоением литеры Ph. Идентифицировали возбудителей фитофтороза с помощью микроскопического анализа посредством Levenhuk DT750 5,3 МПикс [6]

\section{Получение культурального фильтрата}

\section{и изучение фитотоксической активности}

Изоляты Ph.infestans культивировали на жидкую питательную среду Хелла, в состоянии покоя при температуре $18 \ldots 20^{\circ} \mathrm{C}$ в течение 30 дней. Затем отфильтровывали культуральную жидкость и автоклавировали при $120^{\circ} \mathrm{C}$ в течение 30 мин. После определяли фитотоксическую активность изолятов гриба Ph.infestans. Для этого предварительно продезинфицированные 96\% этиловым спиртом семена томата сортов Новичок, Земляк, Пикадор, Красный великан; фасоли - Золотая Сакса, пшеницы - Приморская 239, ячменя - Приморский 98, райграса - Московский 74, вики (по 20 шт. для каждого варианта) замачивали в дистиллированной воде в течение 24 часов Чашки Петри с семенами закрывали и инкубировали в термостате при температуре $18 \ldots 20^{\circ} \mathrm{C}$ в течение 5 суток. Через 5 дней проростки семян погружали в фильтрат культуральной жидкости изолятов гриба Ph. infestans и выдерживали в нем в течение 2 час. Затем проростки инкубировали при $18 \ldots 20^{\circ} \mathrm{C}$ в темноте. Через 48 час измеряли длину корней проростков. Фитотоксическую активность культурального фильтрата (ФАКФ) рассчитывали по степени ингибирования роста корней, используя формулу:

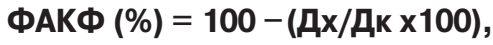

где Дх - средняя длина корней через 48 час в опыте; Дк - средняя длина корней проростков через 48 час в контрольном образце. Токсичными принято считать культуральные жидкости, вызывающие $30 \%$ снижения учитываемых показателей. Отрицательные значения ФАКФ означают стимуляцию роста корней [7].

Оценку всхожести семян в почве на фоне вторичных метаболитов исследуемых изолятов фитофторы проводили в условиях культуральной комнаты в сосудах объемом 5 л. На данный объем автоклавированной почвы (5 л) вносили 4 мл культурального фильтрата, перемешивали и высевали семена, после оценивали всхожесть в процентах. Полученный результат сравнивали с контролем для каждой культуры без внесения фильтрата. Полученные результаты обрабатывали статистически и сравнивали с помощью t-критерия Стьюдента. Различия между показателями считали достоверными при $\mathrm{p} \leq 0,05$. В тексте данные представлены в виде среднего и стандартного отклонения $\left(x \pm S_{x}\right)$ [8]. Графики визуализированы в программе Microsoft Office Excel 2007. 


\section{ISSR-анализ изолятов}

ДНК выделяли солевым методом с дополнительным этапом депротеинизации смесью хлороформ/фенол (1/1) из мицелия, культивированного на картофельно-сахарозном агаре [9]. Для постановки реакции использовали готовую реакционную смесь БиоМастер HS-Taq ПЦР-Color (2x) (Биолабмикс) с добавлением $\mathrm{MgCl}_{2}$ до конечной концентрации $1 \mathrm{mM}$, 50 нг геномной ДНК и 0,3 mМ праймера состава - (GA)8C (Биосан) в конечном объеме 10 мкл [10]. Контроль загрязнения и неспецифической гибридизации праймеров осуществляли холостой пробой, содержащую полную реакционную смесь без добавления ДНК. Амплификацию проводили в термоциклере Т100 (Биорад), используя температурный режим: 5 мин $-94^{\circ} \mathrm{C}$ 35 циклов: $1 \mathrm{мин}-94^{\circ} \mathrm{C}, 1 \mathrm{мин}-55^{\circ} \mathrm{C}, 2 \mathrm{мин}-72^{\circ} \mathrm{C} ; 7$ мин $72^{\circ} \mathrm{C}$ [11]. Амплификат фракционировали электрофорезом в $2 \%$ агарозном геле окрашенном бромистым этидием, фрагменты ДНК визуализировали в гельдокументирующей системе Geldoc XR+ (Биорад). Для оценки длин использовали маркер Step 50 plus (Биолабмикс). Полученные изображения фореграмм обрабатывали с помощью программы GelAnalyzer 19.1 [12]. Расчет генетических характеристик проводили с использованием пакетов программ TFPGA [13].

\section{Результаты и обсуждение}

Материал собирали в период эпифитотии, во время развития характерных симптомов в питомниках картофеля отдела картофелеводства и овощеводства ФГБНУ «ФНЦ агробиотехнологий Дальнего Востока им. А.К. Чайки». Отмечали поражение 80\% посадок картофеля с повреждением органов растений. Микроскопическое исследование изолятов гриба показало наличие мицелия и зооспор, характерных для фитофторы (рис. 1).

Культурально-морфологические признаки семи изолятов были типичными для $\mathrm{Ph}$. infestans c вариациями формы колоний, характера и окраски мицелия, окраски реверса для разных изолятов:

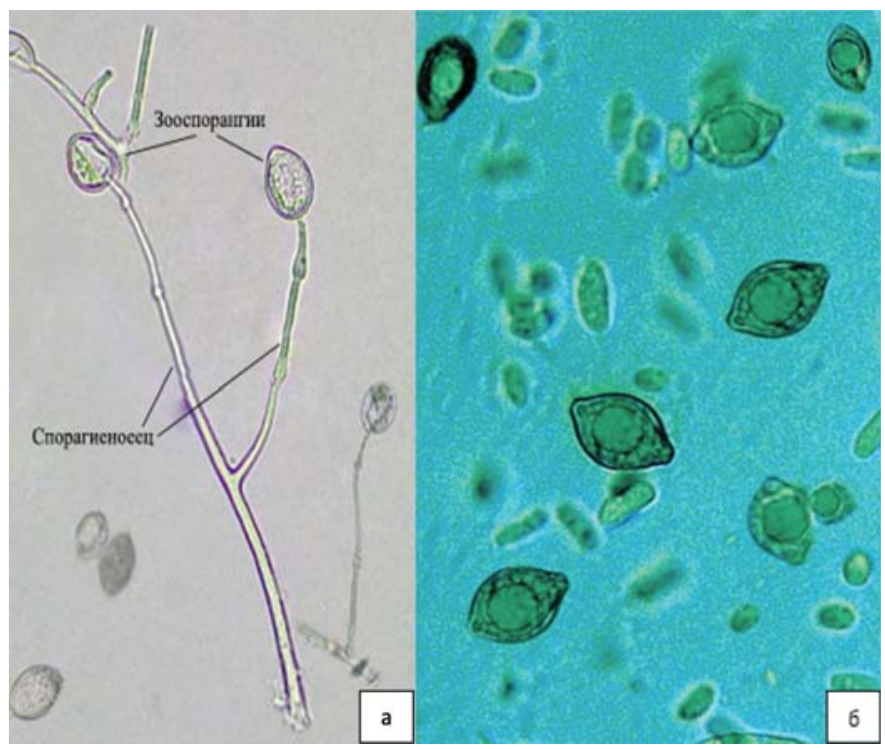

Рис. 1. Морфологические структуры изучаемых изолятов. а -спорангиеносец с зооспорангиями,

$R_{4}$; 6 -зооспорангии, Levenhuck D740T, х60,

зеленый светофильтр (фото авторов)

Fig. 1. Morphological structures of the studied isolates.

a-sporangiophore with zoosporangia,

$\boldsymbol{R}_{4}$; b -zoosporangia, Levenhuck D740T, x60,

green light filter (photos of the authors)
$\mathbf{R}_{\mathbf{1}}$ Колонии белого цвета, хорошо заметные с неровными краями, концентрические. Мицелий прижатый коралловидный, белого цвета. Спороношение обильное.

$\mathbf{R}_{3}$ Колонии беловатого цвет, хорошо заметные. Мицелий шерстистый, плотный, бесцветный.

$\mathbf{R}_{\mathbf{4}}$ Колонии серого цвета. Мицелий ватообразный, жесткий с массовым спороношением, серый. Реверс среды окрашен в малиновый до алого.

$\mathbf{R}_{\mathbf{1}} \mathbf{R}_{\mathbf{2}}$ Колонии беловатого цвета, полупрозрачные, бархатистые с неровными краями. Мицелий прижатый.

$\mathrm{R}_{1} \mathrm{R}_{3}$ Колонии прозрачно-белого цвета, хорошо заметные, с неровными краями. Мицелий прозрачный, прижатый

$\mathbf{R}_{\mathbf{2}} \mathbf{R}_{\mathbf{4}}$ Колонии беловатого цвета, полупрозрачные, хорошо заметные, с неровными краями. Мицелий приподнимающийся, пушистый, тонкий, бесцветный.

$\mathbf{R}_{\mathbf{3}} \mathbf{R}_{\mathbf{4}}$ Колонии белого цвета, войлочные, реверс белый, концентричность слабая.

Для выявления генетических различий и доказательства расовой принадлежности полученных культур был использован ISSR-анализ. На данном этапе исследования было решено использовать только простые расы, выделенные нами в результате выращивания сортов дифференциаторов $-R_{1}, R_{3}$ и $R_{4}$. В результате исследования c использованием праймера (GA)8C амплифицировано 33 фрагмента, 24 из которых оказались полиморфными, уровень полиморфизма составил 72,73\% (рис.2).

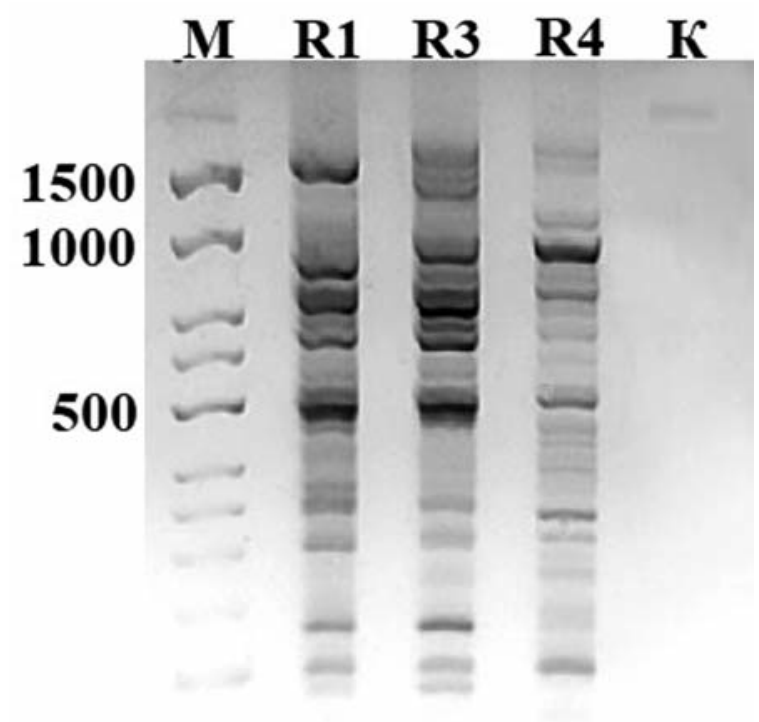

Рис. 2. Электрофореграмма продуктов амплификации используемого праймера. R1-R4 - исследуемые расы фитофторы, M - маркер длин фрагментов Step 50 plus, K контроль реакции

Fig. 2. Electropherogram of the amplification products of the primer used. R1-R4 - studied phytophthora races, M-marker of fragment lengths, Step 50 plus, $K$-reaction control

На основании картины распределения фрагментов были рассчитаны индексы генетических различий (минимальные генетические дистанции Нея - $D_{\mathrm{Nmin}}$ ) для исследуемых рас [14]. Наименьшие различия выявлены в паре $R_{1} / R_{3}(0.2424)$, в то время как $R_{4}$ имеет наибольший уровень отличий как от $\mathrm{R} 1$ так и $\mathrm{R}_{3}(0.6667$ и 0.5455 соответственно) (табл. 1). Для визуализации выявленных различий построена UPGMA дендрограмма филогенетических взаимоотношений исследуемых образцов (Рис.3). 
Таблица 1. Минимальные генетические дистанции Нея простых рас фитофторы по данным ISSR-анализа Table 1. Minimum genetic distances of simple phytophthora races according to ISSR analysis

\begin{tabular}{|c|c|c|c|}
\hline & $\mathbf{R}_{\mathbf{1}}$ & $\mathbf{R}$ & $\mathbf{R}$ \\
\hline $\mathbf{R} 1$ & $* * * *$ & & \\
\hline $\mathbf{R} 3$ & 0,2424 & $* * * *$ & \\
\hline $\mathbf{R} 4$ & 0,6667 & 0,5455 & $* * * *$ \\
\hline
\end{tabular}
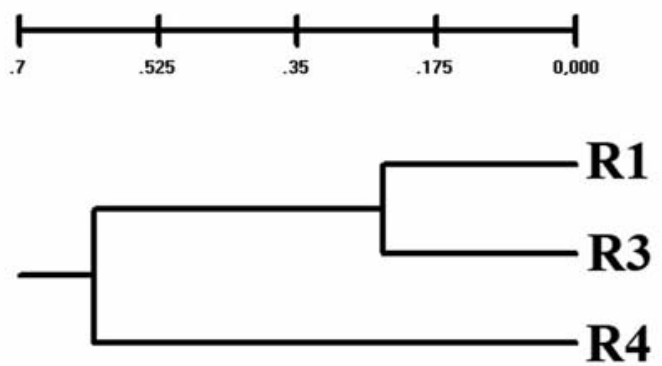

Рис.3. UPGMA дендрограмма филогенетических взаимоотношений простых рас фитофторы по данным ISSR-анализа.

Длина ветвей отражает уровень генетических отличий Fig. 3. UPGMA dendrogram of phylogenetic relationships of simple phytophthora races according to ISSR analysis. The length of the branches reflects the level of genetic differences

Культуральный фильтрат Ph. infestans оказывал фитотоксическое действие во всех вариантах эксперимента. Максимальные значения ФАКФ (100\%) зафиксированы для фасоли, где ингибирование развития проростка наступало при использовании фильтратов большинства изолятов. При этом наименьшее влияние имели фильтрат

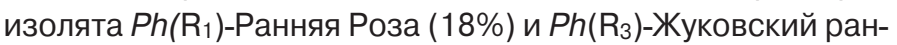
ний (рис.4).

На проростки вики набольшее токсическое влияние

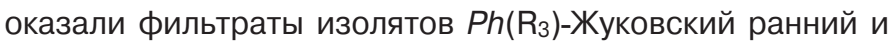

$P h\left(\mathrm{R}_{4}\right)$-Изола, наименьшее - $P h\left(\mathrm{R}_{1}\right)$-Ранняя Роза и $P h\left(R_{1} R_{3}\right)$-Анко. В целом, выявлено очень высокое фитотоксическое действие на исследованные бобовые культуры.

На пшенице наивысшие значения ФАКФ отмечены для фильтрата изолятов $P h\left(\mathrm{R}_{4}\right)$-Изола (100\%), $P h\left(\mathrm{R}_{3}\right)$ Жуковский ранний $(98,5 \%), P h\left(\mathrm{R}_{1} \mathrm{R}_{2}\right)$-Невский $(85,4 \%)$, $P h\left(R_{1} R_{3}\right)$-Анко (81,8\%). Наиболее низкие - для культурального фильтрата изолятов $P h\left(\mathrm{R}_{1}\right)$-Ранняя Роза (70,9\%), Ph( $\left.\mathrm{R}_{2} \mathrm{R}_{4}\right)-$ Красноуфимский $(70,9 \%)$ и $P h\left(\mathrm{R}_{3} \mathrm{R}_{4}\right)-$ Эпока $(72,7 \%)$. На ячмене высокое фитотоксическое действие имели фильтраты всех изолятов. На проростки райграса большинство культуральных фильтратов оказали высокое токсическое действие, кроме $P h\left(R_{1}\right)$ Ранняя Роза, оказавшегося относительно наименее токсичным.

При исследовании влияния фильтратов на проростки томата получен наиболее гетерогенный результат, зависящий от сортовой принадлежности. Фильтраты $P h\left(\mathrm{R}_{1}\right)$ -

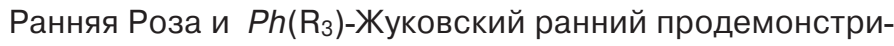
ровали стимулирующее действие на сорт Новичок. Следует отметить, что культуральные фильтраты имели стимулирующее действие для патогенов зерновых и фасоли. При проращивании семян развивалась серая грибница, а в последствии - и спороношение. Для фасоли мы определили возбудителя аскохитоза фасоли (Ascochyta phaseolorum Sacc), для ячменя и пшеницы мучнистой росы (Erysiphe graminis DC). Скрытая инфекция томата проявлялась в меньшей степени и была представлена септориозом (Septoria lycopersici Speg).

Многие из используемых для исследования культур применяют в севообороте при возделывании картофеля, а значит, в случае эпифитотии и массовой гибели картофеля в поле вторичные метаболиты могут накапливаться в почве, что может впоследствии повлиять на всхожесть и развитие сидеральных культур. Для проверки этой гипотезы нами был проведен эксперимент по внесению культуральных фильтратов в почву с после-

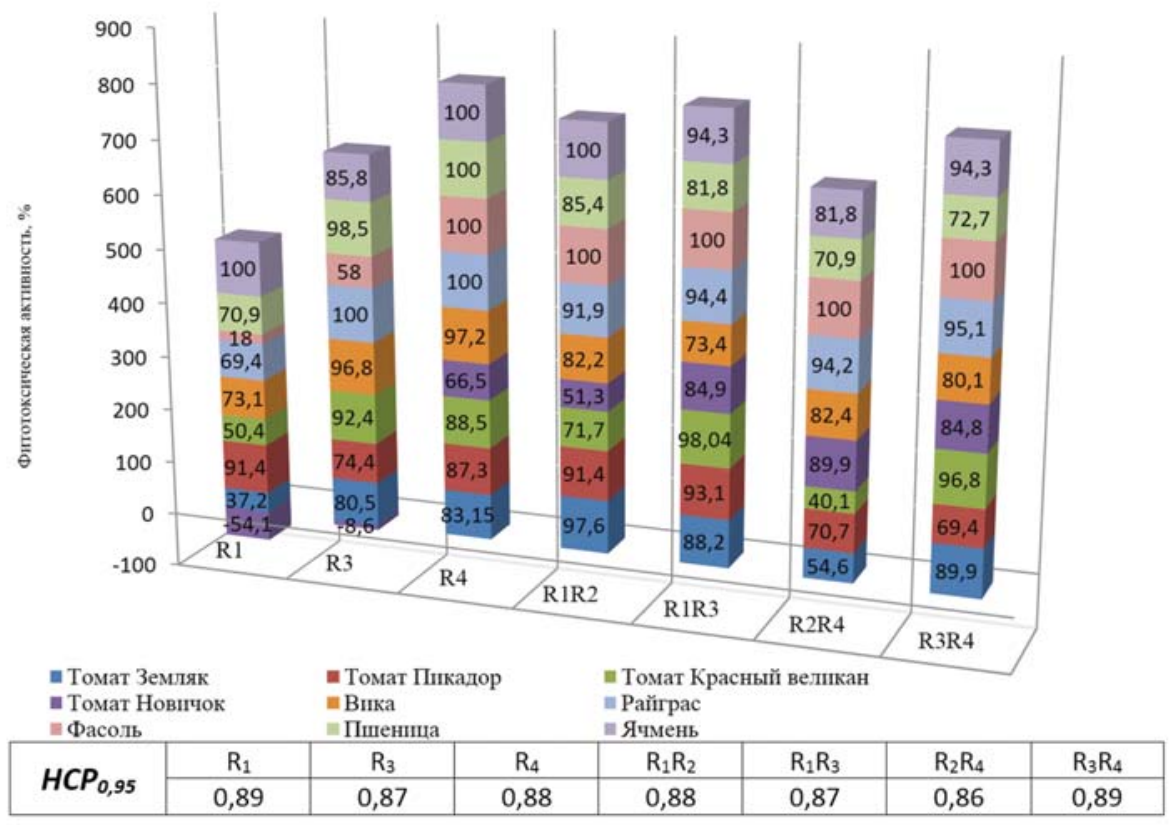

Рис. 4. Фитотоксическая активность изолятов фитофторы на семенах различных культур, \%

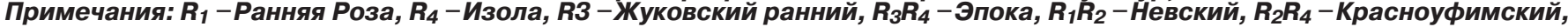

$R_{1} R_{3}-A н к о ; p \leq 0.05$. В сопровождающей таблице приведены данные НСР о.95 для культуральных фильтратов.

Fig. 4. Phytotoxic activity of phytophthora isolates on seeds of various crops, \%
Notes: $R_{1}-$ Rannyaya rosa, $R_{4}-$ Isola, $R_{3}-$ Zhukovsky ranniy, $R_{3} R_{4}-$ Epoka, $R_{1} R_{2}-N_{e v s k y,} R_{2} R_{4}-K$ rasnoufimsky, $R_{1} R_{3}-A n k o$;

$p \leq 0.05$. The accompanying table shows the analysis of variance at the $95^{\text {th }}$ percentile for the culture filtrates. 


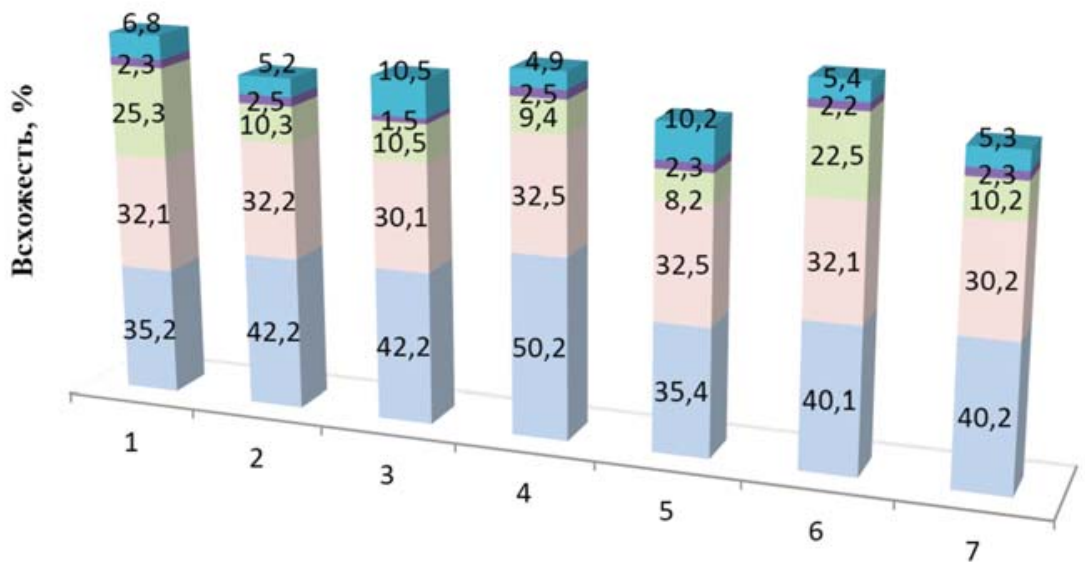

\begin{tabular}{|c|c|c|c|c|c|}
\multicolumn{4}{c}{ ॠартофель } & Томат & Фасоль \\
\hline \multirow{2}{*}{$\boldsymbol{H C P}_{0,95}$} & Картофель & Томат & Фасоль & Ячмень & Пшеница \\
\cline { 2 - 6 } & 0,09 & 0,10 & 0,07 & 0,10 & 0,09 \\
\hline
\end{tabular}

Рис.5. Влияние культуральных фильтратов на всхожесть семян в почве, \%

Примечания: 1 -R1 (Ранняя Роза), 2 -R4 (Изола), 3-R3R4 (Эпока), 4 -R1R3 (Анко), 5 - R2R4 (Красноуфимский), 6 -R3

(Жуковский ранний), 7-R1R2 (Невский); р $\leq 0.05$. В сопровождающей таблице приведены данные НсР 0.95 для всхожести семян культур.

Fig. 5. Influence of culture filtrates on seed germination in soil, \%

Notes: 1-R1 (Rannyaya rosa), 2 -R4 (Isola), 3 -R3R4 (Epoka), 4 -R1R3 (Anko), 5 -R2R4 (Krasnoufimsky), 6 -R3 (Zhukovsky ranniy), 7-R1R2 (Nevsky); p $\leq 0.05$. The accompanying table shows the analysis of variance for the 95th percentile for seed germination of crops.

дующим проращиванием в ней семян картофеля, томата, фасоли, ячменя и пшеницы (рис.5).

В результате эксперимента наименьшая всхожесть зафиксирована для ячменя и пшеницы, фасоль продемонстрировала неоднородный результат, наименьшее токсическое действие зафиксировано для фильтратов: $P h\left(\mathrm{R}_{1}\right)$ -

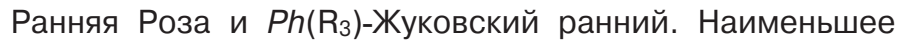
влияние обнаружено для картофеля и томата. Такой результат можно объяснить коэволюцией в системе «патоген-хозяин». Сложившиеся паразитические отношения между паслёновыми и $\mathrm{Ph}$. infestans позволили растениям выработать элиситорные механизмы по отношению к патогену, в то время как для зерновых и фасоли таких взаимоотношений не сложилось. Таким образом, можно предположить, что чем более токсичен фильтрат, тем меньше вероятность паразитических отношений патогена и культуры. При заражении вторичные метаболиты паразита приведут к быстрой гибели хозяина.

Исследования Пролётовой [15] показали, что фильтраты штаммов возбудителей антракноза льна высокотоксичны из-за высокой концентрации цистеина и тирозина, а фильтраты штаммов альтернариоза пшеницы - благодаря альтернариолу [16]. Известно, что Ph. infestans ведет гемибиотрофный образ жизни, имея начальную фазу биотрофной инфекции, во время которой патоген распространяется в ткани хозяина, после чего следует некротрофическая фаза, в которой индуцируется смерть клетки хозяина [17]. На сегодняшний день механизмы поступления питательных веществ от хозяина к патогену во время инфекции практически не изучен, а взаимосвязанный метаболизм патогена и хозяина остается плохо изученным. Достоверно установлено, что фитофторой выделяются метаболиты стероловой группы, а также построе- на интегрированная модель взаимодействия $\mathrm{Ph}$. infestans и томата, заключающаяся в постулате «По мере прогрессирования инфекции Ph. infestans производит меньше de novo синтеза метаболитов и поглощает больше метаболитов из томатов» [17].

Однако данная гипотеза хоть и является значимой, не объясняет фитотоксического действия на культуры, не подверженные фитофторозу паслёновых. По нашему мнению, причину высокого ингибирующего действия фильтратов следует искать в коэволюции системы «патоген-растение». Сложившиеся паразитические отношения между паслёновыми и Ph. infestans позволили растениям выработать элиситорные механизмы по отношению к патогену, в то время как для зерновых и бобовых таких взаимоотношений не сложилось. Таким образом, можно предположить, что чем более токсичен фильтрат, тем меньше вероятность паразитических отношений патогена и культуры. При заражении вторичные метаболиты паразита приведут к быстрой гибели хозяина. Отдельно следует отметить, что метаболиты, возможно, могут накапливаться в почве, особенно в период эпифитотий и стать причиной низкой всхожести сидеральных и овощных культур. Также необходимо обратить внимание на то, что реакция сортов-дифференциаторов должна быть подтверждена искусственным заражением собранными изолятами патогена. Всё вышеизложенное требует тщательного изучения и является предметом наших дальнейших исследований.

\section{Выводы}

В результате выращивания в полевых условиях сортов-дифференциаторов собраны образцы семи изолятов Phytophthora infestans. 
1. В результате культивирования изолятов in vitro выявлены морфологические отличия, выражавшиеся в структуре и окраске мицелия, форме колоний, характере спороношения, цвета реверса и среды под колониями.

2. Выявлены генетические отличия введенного в культуру природного материала фитофторы, собранного с сортов картофеля, имеющие единичные гены устойчивости $\left(R_{1}, R_{3}, R_{4}\right)$.

3. Выявлены отличия в фитотоксической активности

\section{Об авторах:}

Наталия Валериевна Мацишина - кандидат биол. наук, ст.н.с. лаборатории селекционно-генетических исследований полевых культур, автор для переписки, mnathalie134@gmail.com, https://orcid.org/0000-0002-0165-1716 Петр Викторович Фисенко - кандидат биол. наук, В.Н.С, и.о. зав. лаборатории селекционно-генетических исследований полевых культур phisenko@bk.ru, https://orcid.org/0000-0003-1727-4641

Ольга Абдулалиевна Собко - аспирант, М.н.С. лаборатории селекционно-генетических исследований полевых культур, o.eyvazova@gmail.com, https://orcid.org/0000-0002-4383-3390

Ирина Вячеславовна Ким - кандидат С-х. наук, в.н.С.

и.о. зав. лабораторией диагностики болезней картофеля

Дмитрий Игоревич Волков - аспирант, зав. отделом

картофелеводства и овощеводства, volkov_science@inbox.ru, https://orcid.org/ 0000-0002-9364-9225

Наталья Геннадьевна Богинская - М.н.С. лаборатории селекционногенетических исследований полевых культур, cabinet.315@yandex.ru, https://orcid.org/0001-8844-8616

\section{- Литература}

1. Филиппов А.В., Гуревич Б.И., Кузнецова М.А., Рогожин А.Н., Спиглазова С.Ю., Кравцов А.С., Сметанина Т.И., Смирнов А.Н. Горизонтальная устойчивость листьев картофеля к Phytophthora infestans и агрессивность изолятов патогена из разных географических районов. Микол. и фитопатол. 2004:38(5):74-87.

2. Andrivon D., Avendano-Corcoles J., Cameron A.M., Carnegie S.F., Cooke L.R., Corbiere R., Detourne D., Dowley L.J., Evans D., Forisekova K., Griffin D.G. Hannukkala A., Lees A.K., Lebecka R., Niepold F., Polgar Z., Shaw D.S., Thompson J., Trognitz B., van Raaii H.M.G. Stability and variability of virulence of Phytophthora infestans assessed in a ring test across European laboratories. Plant Pathol. 2011;60(3):556-565. https://doi.org/10.1111/j.1365-3059.2010.02392.x

3. Fry W.E., Birch P.R.J., Judelson H.S., Grünwald N.J., Danies G., Everts K.L., Gevens A.J, Gugino B.K. Johnson D.A., Johnson S. B., McGrath M.T., Myers K. L, Ristaino J.B., Roberts P.D., Secor G., Smart C.D. Five reasons to consider Phytophthora infestans a reemerging pathogen. Phytopathology. 2015;105(7):966981. https://doi.org/10.1094/phyto-01-15-0005-fi

4. Caten C.E., Jinks J.L. Spontaneous variability of single isolates of Phytophthora infestans. I. Cultural variation. Can. J. Botany. 1968;(46):329-348. https://doi.org/10.1139/b68-055

5. Костина Л.И., Косарева О.С. Целевая субколлекция селекционных сортов картофеля по устойчивости к фитофторозу. Труды по прикладной ботанике, генетике и селекции. 2019;180(3):36-40. https://doi.org/10.30901/2227-88342019-3-36-

6. Fry WE. Phytophthora infestans, the plant (and R gene) destroyer. Mol. Plant Pathol. 2008;9(3):385-402. https://doi.org/10.1111/j.1364-3703.2007.00465.x

7. Лемеза Н.А. Иммунитет растений: практикум для студентов биол. факультета. Минск, 2008. 94 с.

8. McDonald J.H. Handbook of biological statistics. Third Edition. USA, Baltimore, Maryland: Sparky House Publishing; 2014. 305 pp.

9. Aljanabi S.M., Martinez I. Universal and rapid salt - extracion of high qualiny genomic DNA for PCR - based techniques. Nucleic Acid Research, 1997:25(22):4692-4693. https://doi.org/10.1093/nar/25.22.4692

10. Дьяконов Ю.Т., Еланский С.Н. Популяционная генетика Phytophthora infestans. Микология сегодня. М.: Национальная академия микологии 2007;(1):107-139.

11. www.gelanalyzer.com

12. Nei M. Genetic distance between populations. American Naturalist. 1972;106(949):283-292.

13. Miller M.P. Tools for population genetic analysis (TFPGA) 1.3: a Windows program for analysis of allozyme and molecular population genetic data. 1997 Computer software distributed by author.

14. Пролётова Н.В. Аминокислоты культуральных фильтратов штаммов возбудителя антракноза льна как источники тормоза или индукции морфогенеза льна in vitro. Аграрная наука. 2020;341(9):88-94.

15. Федорович М.Н., Шашко Ю.К, Шашко М.Н., Поликсенова В.Д. Токсичность культуральных фильтратов мелкоспоровых видов рода Alternaria nees. Вестник БГУ. Сер. 2, 2006;(2):36-39.

16. Botero D., Valdés I., Rodriguez M-J., Henao D., Danies G., González A.F. and Restrepo S. A. Genome-Scale Metabolic Reconstruction of Phytophthora infestans With the Integration of Transcriptional Data Reveals the Key Metabolic Patterns Involved in the Interaction of Its Host. Front. Genet. 2018;(9):244. doi: 10.3389/fgene.2018.00244.

17. Rodenburg S.Y.A., Seidl M.F., Judelson H.S., Vu A.L., Govers F., de Ridder D. Metabolic model of the Phytophthora infestans tomato interaction reveals metabolic switches during host colonization. MBio. 2019;10(4):e00454-19. https://doi.org/10.1128/mBio.00454-19 культуральных фильтратов исследуемых изолятов. Наибольшей токсичностью по отношению к бобовым и злаковым культурам обладают вторичные метаболиты изолята $\mathrm{Ph}\left(\mathrm{R}_{4}\right)$-Изола. Пасленовые оказались наиболее толерантными к вторичным метаболитам фитофторы.

4. Можно сделать однозначный вывод о дифференциации представленных образцов на фенотипическом, генетическом уровне и физиологическом уровнях, что позволяет говорить об их принадлежности к расам.

\section{About the authors:}

Nathalia V. Matsishina - Cand. Sci. (Biology), Senior Researcher laboratory of selection and genetic research of field crops, Corresponding Author, mnathalie134@gmail.com, https://orcid.org/0000-0002-0165-1716

Petr V. Fisenko - Cand. Sci. (Biology), Leading Scientist, Acting head laboratory of selection and genetic research of field crops, phisenko@bk.ru, https://orcid.org/0000-0003-1727-4641

Olga A. Sobko - postgraduate student, Junior Researcher laboratory of selection and genetic research of field crops, o.eyvazova@gmail.com, https://orcid.org/0000-0002-4383-3390

Irina V. Kim - Cand. Sci. (Agriculture), Senior Researcher, acting head laboratory of diagnostics of potato diseases Dmitry I. Volkov - postgraduate student, head. Department of Potato and Vegetable Growing, volkov_science@inbox.ru, https://orcid.org/ 0000-0002-9364-9225

Natalya G. Boginskaya - Junior Researcher laboratory of selection and genetic research of field crops, cabinet.315@yandex.ru, https://orcid.org/0001-8844-8616

\section{- References}

1. Filippov A.V., Gurevich B. I., Kuznetsova M.A., Rogozhin A.N., Spiglazova S.Yu., Kravtsov A.S., Smetanina T.I., Smirnov A.N. Horizontal resistance of potato leaves to Phytophthora infestans and aggressiveness of pathogen isolates from different geographical areas. Myc. and phytopathol. 2004;38(5):74-87. (In Russ)

2. Andrivon D., Avendano-Corcoles J., Cameron A.M., Carnegie S.F., Cooke L.R., Corbiere R., Detourne D., Dowley L.J., Evans D., Forisekova K., Griffin D.G., Hannukkala A., Lees A.K., Lebecka R., Niepold F., Polgar Z., Shaw D.S. Thompson J., Trognitz B., van Raaii H.M.G. Stability and variability of virulence of Phytophthora infestans assessed in a ring test across European laboratories. Plant Pathol. 2011;60(3):556-565. https://doi.org/10.1111/j.13653059.2010.02392.x

3. Fry W.E., Birch P.R.J., Judelson H.S., Grünwald N.J. Danies G., Everts K.L. Gevens A.J., Gugino B.K., Johnson D.A., Johnson S.B., McGrath M.T., Myers K.L., Ristaino J.B., Roberts P.D., Secor G., Smart C.D. Five reasons to consider 'Phytophthora infestans a reemerging pathogen. Phytopathology. 2015;105(7):966-981. https://doi.org/10.1094/phyto-01-15-0005-fi

4. Caten C.E. Jinks J.L. Spontaneous variability of single isolates of Phytophthora infestans. I. Cultural variation. Can. J. Botany. 1968;(46):329-348. https://doi.org/10.1139/b68-055

5. Kostina L.I., Kosareva O.S. Targeted sub-collection of potato cultivars specific to late blight resistance. Proceedings on applied botany, genetics and breeding 2019;180(3):36-40. (In Russ.) https://doi.org/10.30901/2227-8834-2019-3-36-40 6 . Fry WE. Phytophthora infestans, the plant (and R gene) destroyer. Mol. Plant Pathol. 2008;9(3):385-402. https://doi.org/10.1111/j.1364-3703.2007.00465.x 7. Lemeza N.A. Plant immunity: a practical course for students of biol. faculty. Minsk, 2008. 94 p. (In Russ)

8. McDonald J.H. Handbook of biological statistics. Third Edition. USA Baltimore, Maryland: Sparky House Publishing; 2014. 305 pp.

9. Aljanabi S.M., Martinez I. Universal and rapid salt - extracion of high qualiny genomic DNA for PCR - based techniques. Nucleic Acid Research, 1997:25(22):4692-4693. https://doi.org/10.1093/nar/25.22.4692

10. Dyakonov Y.T., Elansky S.N. Population genetics of Phytophthora infestans. Mycology today. Moscow: National Academy of Mycology. 2007;(1):107-139. (In Russ)

11.www.gelanalyzer.com.

12. Nei M. Genetic distance between populations. American Naturalist. 1972;106(949):283-292.

13. Miller M.P. Tools for population genetic analysis (TFPGA) 1.3: a Windows program for analysis of allozyme and molecular population genetic data. 1997. Computer software distributed by author.

14. Proletova N.V. Amino acids of cultural filtrates of flax anthracnose pathogen strains as sources of inhibition or induction of flax morphogenesis in vitro. Agrarian science. 2020;341(9):88-94. (In Russ)

15. Fedorovich M.N., Shashko Yu.K., Shashko M.N., Poliksenova V.D. Toxicity of culture filtrates of small-spore species of the genus Alternaria nees. BSU Bulletin. Ser. 2, 2006; (2):36-39. (In Russ)

16. Botero D., Valdés I., Rodríguez M-J., Henao D., Danies G., González A.F. and Restrepo S. A. Genome-Scale Metabolic Reconstruction of Phytophthora infestans With the Integration of Transcriptional Data Reveals the Key Metabolic Patterns Involved in the Interaction of Its Host. Front. Genet. 2018;(9):244. doi: 10.3389/fgene.2018.00244.

17. Rodenburg S.Y.A., Seidl M.F., Judelson H.S., Vu A.L., Govers F., de Ridder D. Metabolic model of the Phytophthora infestans tomato interaction reveals metabolic switches during host colonization. MBio. 2019;10(4):e00454-19. https://doi.org/10.1128/mBio.00454-19 